This is an electronic reprint of the original article. This reprint may differ from the original in pagination and typographic detail.

Author(s): Kontinen, Tanja; Ojala, Arto

Title: $\quad$ Social capital in the international operations of family SMEs

Year: $\quad 2012$

Version:

Please cite the original version:

Kontinen, T., \& Ojala, A. (2012). Social capital in the international operations of family SMEs. Journal of Small Business and Enterprise Development, 19(1), 39-55. https://doi.org/10.1108/14626001211196398

All material supplied via JYX is protected by copyright and other intellectual property rights, and duplication or sale of all or part of any of the repository collections is not permitted, except that material may be duplicated by you for your research use or educational purposes in electronic or print form. You must obtain permission for any other use. Electronic or print copies may not be offered, whether for sale or otherwise to anyone who is not an authorised user. 


\title{
Social capital in the international operations of family SMEs
}

\author{
Tanja Kontinen and Arto Ojala
}

\begin{abstract}
Purpose - The aim of this study is to discuss how social capital is developed in the internationalization process of small and medium-sized family enterprises (family SMEs).
\end{abstract}

Design/methodology/approach - This paper reports findings from an in-depth multiple case study with four Finnish manufacturing family SMEs. The data were analyzed through the perspectives of (i) structural holes, (ii) network closure, and (iii) the interplay between these two mechanisms.

Findings - Our material demonstrated that family entrepreneurs had a large number of structural holes when launching international operations, but also after several years of running international operations. Instead of trying to span structural holes, they concentrated merely on developing the network closure with agents and subsidiary staff. The case firms spent a lot of resources on finding suitable network ties and on developing good network closure with the selected social capital ties.

Research limitations/implications - There are some aspects that might differ depending on the home and target country of firms. For instance, firms in some Asian countries are able to utilize emigrant relationships that help them with networking, which was not the case here with Finnish family SMEs.

Practical implications - Family entrepreneurs seem to have a tendency to concentrate on a limited number of foreign partners, and to neglect the building of new relationships that could help them in future challenges.

Originality/value - In this study, we (i) respond to calls for more research on network development in the entrepreneurial process, especially in the context of internationalization, (ii) we introduce the notions of network closure and structural holes to the internationalization context, and (iii) we reveal how social capital restricts and facilitates family SMEs' international operations.

Keywords family SMEs; social capital; network closure; structural holes; foreign operations

Paper type Research paper 


\section{Introduction}

Social capital has attracted the interest of researchers in various research fields for several decades (e.g. Adler and Kwon, 2002). Social capital is essentially dynamic, being dependent on network development: the capital can increase or decrease as firms deepen existing relationships, establish new ones, and end problematic ones (Jack et al., 2008; Larson and Starr, 1993; Rauch, 2001). An understanding of this kind of network development is clearly important for research on entrepreneurship (Hoang and Antoncic, 2003; Jack, 2010; Jack et al., 2008) since changes in the network will affect the further development of the firm (Coviello, 2006; Jack, 2005), including any internationalization processes that are undertaken (Chetty and Agndal, 2007). However, much remains to be discovered about networks and their development in the entrepreneurial process, (Jack, 2010), and there have been calls for qualitative research to increase understanding of the phenomenon (Hoang and Antoncic, 2003; Jack, 2010).

Especially among SMEs, network ties between employees are tightly integrated, and changes in the network structure have more effect than in large multinationals. Family SMEs are highly suitable for research on social capital; indeed, social capital has been proposed as a particular feature of family-owned businesses, on account of the close ties between family members (Salvato and Melin, 2008). Nevertheless, although close ties between family members and employees create social capital, it has been argued that such ties may restrict access to new and valuable information outside the firm (Burt, 1992; Granovetter, 1973). 
In the international context, we have very limited knowledge of how family firms develop their network ties outside the firm during the internationalization process (Kontinen and Ojala, 2010). For these reasons, the broad aim of this study is to determine how family SMEs develop their social capital during the progress of international operations, and to examine how, within this course of events, two posited mechanisms, namely (i) network closure, and (ii) structural holes, interact with each other. These mechanisms will be discussed in Section 2 below, which will be followed (Section 3) by a statement of our more specific research questions.

\section{Concepts and definitions}

\subsection{Social capital}

Social capital differs from other types of capital (such as financial, physical, or human capital), since it is a form of capital that is not located within a certain place, being rather embedded in relationships between actors in a social network (Adler and Kwon, 2002; Coleman, 1988; Nahapiet and Ghoshal, 1998). In the study reported here, we use the definition by Nahapiet and Ghoshal (1998, p. 243): social capital is "the sum of the actual and potential resources embedded within, available through, and derived from the network of relationships possessed by an individual or social unit." The dynamic nature of social capital indicates that it may increase or decrease as firms deepen existing relationships, establish new ones, and end problematic ones (Larson and Starr, 1993; 
Rauch, 2001). It should be noted that social capital may not be advantageous in every case. For instance, a close network can limit the group's access to new information and new ways of doing things; or social capital partners may prove untrustworthy, leading to a reduced performance for the firm (Nahapiet and Ghoshal, 1998). Nevertheless, having only limited social capital is usually detrimental: the less social capital a firm has, the more it is exposed to opportunistic behavior, and the more difficult it may be to build long-term relationships (Walker et al., 1997).

\subsection{Structural holes and network closure}

The two most important network mechanisms providing social capital are structural holes and network closure (Burt, 1992; Coleman, 1988). The traditional view of social capital emphasizes the positive effects of network closure, i.e. cohesive ties, in terms of social network benefits (Coleman, 1988). However, according to structural hole theory (Burt, 1992), social capital stems from the possibilities permitted by separate ties, i.e. by a lack of network closure. On the face of it, these theories represent opposing views on how networks create social capital.

According to the structural holes theory (Burt, 1992), the benefits of social capital result from the diversity of information and the brokerage opportunities created by the lack of connections between separate groups in social networks. Structural holes (gaps, lacunae in networks) permit a competitive advantage for a person (or firm) whose relationships span the holes. Individuals whose networks have only a limited number of 
structural holes know and have control over more rewarding opportunities. Based on this, a structural hole is here defined in the words used by Burt (2005, p. 25) as "a place in a network that could create value. A structural hole exists between two people or groups when either party is unaware of the value available if they were to coordinate on some point." Relationships acting as bridges to other groups, such as firms, can result from events such as the setting up of cross-functional teams, inter-organizational conventions, or professional meetings bringing together people from different groups (Burt, 2000). Network brokerage can also be indirect, if there is a strong connection to a person/firm with a strong connection to someone else who is important for the firm (Burt, 2010). This can be the case, for instance, if the foreign agent of the firm has strong relationships with customers whom the headquarters staff do not know at all.

Network closure is created by a network of strongly interconnected persons (Burt, 2000). It emphasizes the positive effect of cohesive social ties in the creation of social capital. Hence, network closure refers to networks in which everyone is connected in such a way that no one can escape the notice of others, which in operational terms usually means a dense network (Coleman, 1988). Social norms are given "closure" when two or more individuals recognize that it is advantageous for their interests to cooperate. In a closed network "people have strong relations with one another or can reach one another indirectly through strong relations to mutual contacts" (Burt, 2010, p. 251). In the first place, closure facilitates access to information, because another person in the network can briefly convey what is essential, and knowledge sharing is efficient. Secondly, network closure facilitates sanctions, and this has the effect of enhancing the level of 
trust in the network. When people have strong relations in their network, they get more reliable communication channels; furthermore, they are protected, because by means of their contacts they are better able to cooperate against someone who does not obey the network's norms (Burt, 2000; Coleman, 1988).

These two network mechanisms refer to a different means of creating social capital. Yet although they have been regarded as opposed to each other, they have also been seen as complementary mechanisms (Burt, 2000; Gargiulo and Benassi, 2000; Podolny and Baron, 1997). Burt (2000) found that the performance of a firm is the highest when the firm achieves high levels in both network closure and the number of non-redundant contacts beyond the firm. Networks that span structural holes may provide the manager with timely information about new opportunities, whereas cohesive ties are needed to exploit those opportunities (Podolny and Baron, 1997). According to Burt (2010, p. 151), "[w]here brokerage is about vision and growth from expanded horizons, closure is about control and productivity associated with people aligned on a shared goal."

According to Gargiulo and Benassi (2000), these two mechanisms cannot be maximized simultaneously, since the trade-off between safety (i.e. network closure) and flexibility (i.e. structural holes) is inherent to the dynamics of social networks. In the context of the formation of inter-organizational ties, organizations prefer to form embedded ties ${ }^{1}$ (Gulati and Gargiulo, 1999), which may lead to network closure. In a later phase, when organizational change is needed, the flexibility offered by structural holes may be more important than network closure.

\footnotetext{
${ }^{1} E$ mbedded here refers that the ties are an integral part of a surrounding whole.
} 


\subsection{Social capital and internationalization in family firms}

Important factors related to social capital and internationalization in family firms are, for instance, their: (i) unusual devotion to continuity, (ii) tendency to nurture the community of employees very carefully, and (iii) search for closer connections with customers and partners in order to sustain the business (Miller et al., 2008). These factors are related to both the internal/familial and the external social capital of family firms. Internal capital is based on strong internal relationships and interactions composed of the aspirations and capabilities of family members (Salvato and Melin, 2008), which can be assumed to have an effect on the manner in which family firms build and develop external social capital. Strong internal social capital can reduce transaction costs, and it can facilitate information flows, knowledge creation and accumulation, and creativity (Arregle et al., 2007; Burt, 2000). However, internal networks do not result in faster internationalization; in fact they may become a liability by hindering the flow of information and blocking links to new contacts (Musteen et al., 2010).

External social capital connects family firms to diverse networks. It is the result of family firms' interactions, communications and relationships with diverse external stakeholders, and it makes it possible to obtain resources from other companies (Arregle et al., 2007). Networks of this kind are needed if the firm is to innovate and succeed. Family firms have been shown to have a limited number of external network ties in comparison to non-family firms (Graves and Thomas, 2004). This can be seen as a 
consequence of their strong internal social capital (Arregle et al., 2007; Salvato and Melin, 2008). However, external social capital ties prevent family firms from becoming too conservative and unable to adapt to environmental changes (Miller et al., 2008).

As regards internationalization, family involvement in management has been seen as factor tending towards caution in the internationalization processes of family firms (Claver et al., 2008). There is evidence that family firms are less likely to internationalize than non-family firms (Graves and Thomas, 2006). If family firms internationalize, they do it mainly incrementally, proceeding step by step (Graves and Thomas, 2008). In addition to a lack of external network ties, the reasons for the cautious and incremental internationalization might be, for instance, their limited growth objectives, avoidance of risk, restricted financial capital, and limited managerial capabilities (see Kontinen and Ojala (2010) for further review).

\section{Aims, critique and research questions}

In this paper we aim to contribute to research on social capital and firm internationalization by modifying network closure and structural holes perspectives in ways appropriate to the context of firm internationalization. Although the literature review here clearly demonstrates the important role of social capital, in general, and especially in the context of family firms, we do not know much how the two network mechanisms, i.e. structural holes and network closure, explain (separately and together) the internationalization of family firms (see also Kontinen and Ojala, 2010). This is 
important especially for family SMEs in which relationships between employees are commonly close and highly integrated. The broad issue addressed in this study can be phrased as follows: How do network closure and structural holes explain the development of international operations among family SMEs? This can be addressed via three specific research questions which we shall focus on in our observations: 1. How do the international operations of family SMEs develop in terms of structural holes? 2. How does network closure develop in the international operations of family SMEs? 3. How do family SMEs bridge structural holes and develop network closure in their international operations?

\section{Methodology}

Since the objectives of this research were more related to understanding than to measuring (Jack, 2005), and since current understanding of the dynamics of bridging social capital in the context of family SMEs is limited, a qualitative research method was regarded as most appropriate for this study. Social capital is "an aggregate concept that has its basis in individual behavior, attitudes, and predispositions" (Brehm and Rahn, 1997, p. 1000) - an aspect which further strengthens the need for a qualitative study, since the focus is on studying the processes, contents and dynamics of networks consisting of individuals (Coviello, 2006; Jack, 2005, 2010; Prashantham and Dhanaraj, 2010).

For this study, we selected a multiple-case study with four family SMEs operating in the French market. Finland was chosen as the country of origin because it 
has a small and open economy with a very limited domestic market (OECD, 1997) wehre the internationalization is an important growth strategy. The choice of the French market as the context made it possible to investigate the dynamics of social capital in a particular context, one that would be similar for all the firms involved in the study.

As far as the definition of a family firm is concerned, it can be defined as one in which the family (i) controls the largest block of shares or votes, (ii) has one or more of its members in key management positions, and (iii) has members of more than one generation actively involved within the business. This definition is based on the two criteria of ownership and management presented, for instance, by Graves and Thomas (2008), and on the factor of continuity (see for instance Zahra, 2003). All the case firms were from the manufacturing sector and had fewer than 250 employees at the time of entry to the French market. Thus, they fulfilled the criteria of the Finnish government and the EU for classification as SMEs (OECD, 2003).

Multiple sources of information were used to gather data from each case firm. The main form of data collection was a semi-structured interview, guided by a list of topics. The interviews were conducted by one of the authors, a researcher who was fluent in English and French, and who had experience of living in French-speaking countries. The interviewer followed the guidelines set out by Huber and Power (1985) to minimize the risk of providing inaccurate or biased data. Altogether, eleven semi-structured openended interviews lasting 60-100 minutes were conducted with two or three respondents 
from each firm², in the firm's headquarters in Finland and in its subsidiary/agency in France. The interviewees selected had in-depth knowledge of internationalization and operations in France. Having two or three interviewees from each case firm we aimed to get the most relevant knowledge, and to counteract the biases of individual opinions (Huber and Power, 1985).

Following Svendsen (2006), at the start of the interview, neutral and nonthreatening questions were asked to establish a relationship of mutual trust. The interviewees were first asked to describe their business in general, thereafter their operations related to internationalization as a whole, and from that the business connected to internationalization in France in particular. Once the main issues of the interview had been touched on, short questions, such as "Could you describe this? How? Why?" were posed to go deeper into the issue. Social capital in the process of entry to the French market was discussed through the following issues: (i) important events, persons, firms, or organizations that influenced the entry process, (ii) the development of relationships after the initial entry, and (iii) considerations relating to how and why the relationships developed in such a way. All these questions were developed according to the guidelines issued by Yin (1994), with the aim of making the questions as non-leading as possible.

All the interviews were digitally recorded and transcribed verbatim. A second listening was conducted to ensure correspondence between the recorded and the transcribed data. The complete case reports were sent back to the interviewees and any

\footnotetext{
${ }^{2}$ Two from the small firm B (employing fewer than 50 persons), and three from middle-sized firms A, C, and D.
} 
inaccuracies they noticed were corrected. In addition, e-mail communication was used to collect further information and to clarify any inconsistent issues. To improve the validity of the study we collected and analyzed many types of secondary information (such as websites and annual reports). By comparing the interview data with other documents from the case firms, we carried out triangulation on the information (Miles and Huberman, 1994).

In the data-ordering phase, a detailed case history of each firm was formed, based on interviews and written documents. Pettigrew (1990) suggests that organizing incoherent aspects within a chronology is an important step in understanding the causal links between events. In our data analysis phase, cross-case pattern searching was utilized. The unique patterns of each case were identified and similar patterns were categorized under broad themes, on the basis of the research questions in the study. In addition, checklists and event listings were used to identify critical factors (Miles and Huberman, 1994) related to determinants that might involve social capital.

To make the theoretical constructs of structural holes and network closure suitable for this study we have modified them to make them suitable for the international operations context. To illustrate the role of structural holes and the extent to which the case firms have bridges spanning these holes, the number of bridges is regarded as high or low. The number of bridges in the network of a firm is regarded as low if the firm has no contacts in the target market, and if in foreign operations it does not have any contacts other than foreign agents/subsidiary staff. The number of bridges in the network of a firm is regarded as high if the firm has several contacts in the target market 
when planning foreign operations, or many contacts in addition to the ones it does business with. The level of network closure is regarded as:

(i) Strong if the relationship with the foreign cooperator(s) is close, based on trust, mutual respect, open communication, commitment, similar values, a passion for the field, and freedom to act according to one's own personality and creativity.

(ii) Medium if there are only two or three of the following features in the relationship with the foreign cooperator(s): closeness, trust, mutual respect, open communication, commitment, freedom to act according to one's own personality and creativity.

(iii) Weak if the relationship with the foreign cooperator(s) has most of the following features: distance, a lack of trust, a lack of mutual respect, a lack of open communication, a lack of freedom, and a lack of commitment.

\section{Findings}

Figure 1 illustrates the most important social capital ties of the case firms in the French market and the strength and development of these ties. Firstly, we shall very briefly discuss each firm and its network development in the French market. Secondly, we shall discuss in detail the development of the firm's social capital in the context of its international operations, making use of the structural holes and network closure perspectives. 


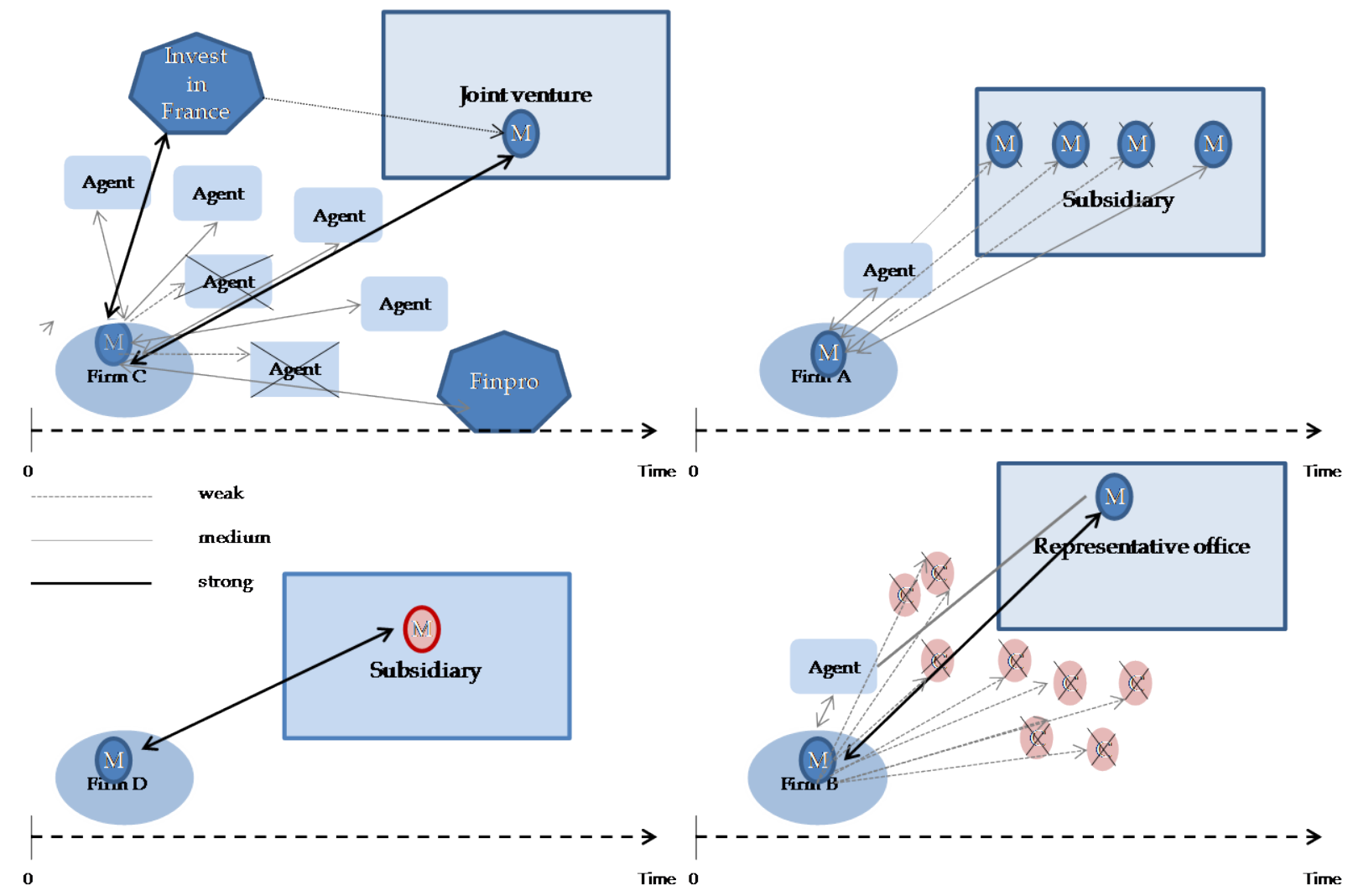

Figure 1. Development of social capital within the case firms (upper right quadrant $=$ Firm A, lower right = Firm B, upper left = Firm C, lower left = Firm D).

\subsection{The firms' network development}

The stories behind the firms are important in order to situate the phenomenon under study, i.e. the development of social capital, in particular contexts. The following paragraphs will briefly present these stories. Firm A, which provides office equipment and manufactured products made of sheet metal, was established in 1876. In 1970, Firm A started exporting to the Nordic countries. In 1980, exporting was expanded to 
Germany, and in 1982 export to France was launched. The agent that took care of the exports was found at an international exhibition, when Firm A was looking for suitable partners to increase its international sales. The relationship with the agent developed quickly and led to the establishment of a subsidiary in France, in 1984. Since then, cooperation in the French market has been problematic for Firm A, since it has been forced to change the subsidiary manager three times.

In the case of Firm B, which manufactures log houses, internationalization started in 1994, 21 years after the establishment of the firm (1973), with the export of log houses to Germany and Japan. The French trade started in 1998 in the form of exporting. The entry to the French market was based on the initiative of a French person who saw potential in selling the villas abroad. The relationship between the entrepreneur and the French agent very soon became strong. It was intended that a network of distributors would be formed, but the attempts to find reliable people in the French market failed. Hence, a representative office was established in France in 2002 with a view to facilitating administration.

The story of Firm C, currently run by the second generation, began in 1972 . This firm manufactures different kinds of packaging materials. Poland was its first export market (1985). The firm exported to ten European countries and had a subsidiary in Poland before it entered France in 1989. Originally, four agents were found at international exhibitions; the relationship with them was something between strong and weak until two agents were replaced by better ones, also found at international exhibitions. Firm C wanted to strengthen its presence in Central Europe and looked for 
suitable production opportunities in France through two intermediary organizations, Invest in France and Finpro. A suitable partner was found through Invest in France, and a joint venture involving a production plant was established in 2006.

Firm D was launched in 1988 by an experienced entrepreneur. This firm produces various products including pipettes and analyzing systems. It is important to note that before the entrepreneur set up Firm D, he had run two similar kinds of businesses in the same field; his social capital from previous businesses was so strong that the establishment of the first foreign subsidiaries happened almost by itself. The French subsidiary was the first subsidiary to be established, in 1991.

\subsection{Structural holes}

In Firms A, B, and C, there was no existing social capital for entry into the French market. Hence, these family SMEs had a low number of bridges and their French foreign market entry was based on the formation of new social capital. Firm D is the only one that was able to utilize its existing social capital for the French entry: a previous business partner and friend resigned from his job and launched a subsidiary, three years after the owner-manager established Firm D. This subsidiary manager had also managed the preceding French subsidiary of the owner-manager.

As regards research question 1 (concerning the spanning of structural holes in post-entry international operations), Firms A and D have sought to develop new bridges only to a very limited extent, while Firm B looked for French bridges only right after the 
initial foreign market entry. Firm $\mathrm{C}$ has been the most active and successful in developing post-entry bridges and the only one with a high number of bridges in the French market. Firm $\mathrm{C}$ has renewed two of its agents by attending international exhibitions, cooperated with intermediary organizations, and established a production joint venture in France. The joint venture partner was found through an agency (called Invest in France) which gave them a great deal of help.

As regards Firm B, after the initial FME, the entrepreneur and the French agent of Firm B drove together around France, searching for local retailers for their log houses (the prospective retailers are marked as C, standing for "candidate" in Figure 1). However, all the candidates contacted were found unsuitable, and Firm B went on to set up a representative office instead of a retailer network. Since then, bridges have been built to a more limited extent. Firms $\mathrm{A}$ and $\mathrm{D}$ have been inactive in developing bridges in the French market. Firm A has on three occasions been in a situation where they have needed to replace the existing subsidiary manager. However, since Firm A's habit has been to search for new cooperators only when there is a true need for it, they have operated on opportunistic lines, recruiting from among their existing staff. As far as Firm D is concerned, the existing, trustworthy network tie in the French market has been found so reliable that the firm has not looked for any other cooperators there, 


\subsection{Network closure}

Generally speaking, all the case firms seem to have regarded the development of network closure as very important in their international operations, investing time on finding trustworthy partners and also on maintaining established relationships. As Figure 1 illustrates, most companies have succeeded in finding one trustworthy French partner with strong network closure (marked with a thick, black arrow), but many of the case firms have nevertheless had to cooperate with partners with medium network closure (marked with a gray arrow). Furthermore, most firms have network ties that belong to the category weak network closure. In some cases (see Firms A and C especially), a formerly medium network tie became a weak one and has, as a result, terminated. This illustrates the dynamics of network closure, in which problematic partnerships are ended and new ones established. These are important features in terms of research question 2 concerning network closure in the context of international operations. In the following sub-sections, the focus will be on (i) strong/strengthening, (ii) medium, and (iii) weak/weakening network closure among the case firms.

Strong/strengthening network closure. In Firm D, there was extremely strong network closure between the owner-manager and the French subsidiary manager. Both the owner-manager and the subsidiary manager emphasized respect, total trust, similar values, and a passion for the field as the secret of their extremely strong relationship, which had never had setbacks. The subsidiary manager expressed it thus: 
What makes our relationship unique is respect for each other and inspiration regarding our field. We seem to see the world in the same way, we share values. He does not think about money so much, all the other aspects come first. And he also gives total freedom to me. I feel so comfortable with being able to run the French subsidiary my way. He always trusts me: if I want to do something, he says, yes, do that, you know what is best for you there.

Firm C's joint venture partner was described in fairly similar terms, with the resemblances between the two firms being emphasized. Like Firm $C$, the joint venture partner was $100 \%$ family-owned, and hence also a firm with family values, and the sizes of the two firms were fairly similar. The commitment of the French joint venture partner was crucial in the development of a good relationship, and their network closure became strong very soon after the two parties realized that they had common interests. In terms of the strong network closure perspective, Firm B, too, displays strong network closure between the owner-manager and the French agent. The French agent even took out a large personal loan to carry out his ideas for selling the log houses.

In Firms B and C, the finding of strong partnerships was based both on serendipity and on active search. However, Firm D was different; since the network closure between the French subsidiary manager and the owner-manager of Firm D was already strong before the launch of the French subsidiary. Furthermore, this relationship has been the most stable one. Although the present subsidiary manager had had a profitable subsidiary to run and although he was offered double the wages he was getting, he decided to start a new subsidiary for Firm D from scratch. All this illustrates how significant strong social capital ties can be when an international business is launched. Instead of having to concentrate on the initiation of network ties (as in the cases of Firm 
$\mathrm{B}$ and $\mathrm{C})$, the co-operators were able to concentrate on subsequent closure. The subsidiary manager explained his decision in the following manner:

They offered me a five-year agreement and they offered to double my salary from the company where I was working. I said "No, I'm leaving. I have decided I'm leaving." In Firm D, I like it that you have a certain way of doing business, meaning that there is business, but there is private life as well. With the Finnish companies, the human relationship is very important as well. And it is very important for me, too. And that is the main reason why I am still working with him.

The French subsidiary has achieved very good results and has grown substantially. The subsidiary manager has given the same freedom to the subsidiary employees that was given to him by the Firm D manager, and he sees this as the secret of their success:

I believe in people and letting them do things. So that they can create things in a positive way. If you don't let people express themselves you won't get as much as they can give. In order to be competitive, you need to have a team which is happy to work for the firm.

Medium network closure. Relating to research question 2 concerning the development of network closure in international operations, we present below features connected to a medium level of network closure. Closeness and commitment remain essential features in such a level of network closure. Firm A's subsidiary sales assistant described the relationship as follows:

I would say they (the Finns in the headquarters) are very nice people, no problems with that. It's a kind of family. We have relations with colleagues that have been so long in the company. And we know all the people in the company and the management. Really, I would not like to leave, because I feel at home here.

In the case of Firm B, similar kinds of values were mentioned by the informants as present from the beginning of their relationship: mutual trust, closeness and an interest in cooperation. But by contrast, trust and respect seem to be qualities that can be lacking 
in a relationship with medium network closure. Firm's A current subsidiary manager and the subsidiary sales assistant explained the lack of trust and mutual respect in the headquarters-subsidiary relationship in the following terms:

When for example we explain that we should get a lighter range, they do not consider this. They listen to what you say, it is an open discussion, but it does not mean that anything happens... That is why I cannot really trust them. They always have an answer to my questions, but it is not really a good one. For example when they came to us here in the French subsidiary for a couple of days, they weren't discussing with us, just checking how we were working, and there's also the fact that they are producing these items and then thinking how we should sell them.

In Firm C, too, there have been various social capital ties with medium network closure. Over a period of fifteen years, two of these agents have been replaced by better ones, due to the weakening of network closure. The best ones have been able to continue cooperation.

Weak/weakening network closure. A third perspective on research question 2, concerning the development of network closure in the international operations of family SMEs, is gained by examining weak/weakening network closure and the features underlying it. From the point of view of the headquarters, a weaker than expected level of network closure could be related to too high a level of control and to irregular communication with the subsidiary. The international sales manager at the headquarters of Firm A said:

It started very well, but there were problems, because they did not want to follow our rules. And now, since then, I have also understood that we left them alone too much. We also experienced some misbehavior, because they realized that we did not control them. It is so important for the French to have a feeling of togetherness, but we had things too much like "us here" and "you there". 
The point of interest here us that the weakening of the originally trustworthy relationship with the subsidiary managers was also connected to too strong a belief that things would go well in France without a high level of control. Interestingly, from the headquarters point of view, there was also a problem with learning to know how the subsidiary employees felt about their managers. The manager of international affairs in Firm A explained the lack of openness in the following way:

In France, the managers seem to have a very strong position. First of all, the employees do not voice judgments on their bosses to outsiders. We had several occasions when we realized that something was wrong in the subsidiary, but we just did not get any comments on it. They just could not say straight out what they thought of their boss.

For Firm B, the formation of network closure with French retailers was very hard. Since they knew no potential French cooperators, the entrepreneur and the French agent travelled around France and discussed the matter with interested parties. Dozens of candidates were commissioned and many more were met, but they all failed to sell the Finnish log houses. In fact, there was not even a medium level of network closure with the new candidates. The network closure remained at a low level, since none of the potential retailers did what they promised. The entrepreneur explained their search for candidates as follows:

We started by searching for local partners. They told us about the needs of the customers, we made the offers and they passed them on to customers. We played with these potential partners for many years, but none of them turned out to be trustworthy or able to sell. They just took our time and money. On one of the trips we went to Paris and met a man who ordered 30 log houses. And none of them were actually delivered. He just cheated us. 
This had in fact caused some financial loss to Firm B. With four years' experience of searching for suitable partners in France, Firm B ended up establishing a representative office in Paris, in 2002.

\section{Discussion}

In terms of structural holes, our material demonstrated that family entrepreneurs had a large number of structural holes in their foreign markets, especially when launching international operations, but also after several years of running international operations. Instead of trying to span structural holes, they concentrated merely on developing the network closure with agents and subsidiary staff. This led the family entrepreneurs to serendipitous procurement in their international operations: their international networks were limited, and they only started searching for new cooperators when there was a true need for it, at which point they behaved opportunistically. The need for a new network tie usually emerged after a network tie was proved weak. Since family entrepreneurs did not generally have ready-made partnerships in the target market, they went and looked for them at international exhibitions, or else they took on the search purely by themselves. The generally emerging pattern was that instead of seeking to span structural holes internationally, the family SMEs in this study concentrated on the development of network closure with a very small number of partners in their international operations. This large number of structural holes, in turn, led to serendipitous procurement in internationalization. 
Altogether, as regards research question 2 on the development of network closure, all the case firms spent a lot of resources on finding suitable network ties and on developing good network closure with the selected social capital ties. Yet despite the efforts, network closure between the headquarters and the subsidiaries/agents was often somewhat limited. Network closure was strong when the headquarters and the subsidiary/joint venture/representative office staff had a relationship based on respect, total trust, similar values, open communication, commitment, passion for the field, and freedom to act according to one's own personality and creativity. The medium type of network closure was based on closeness and commitment, but trust and respect were generally lacking. As regards weak/weakening network closure, in the case of headquarters-subsidiary cooperation the problems were related to poor knowledgesharing and the possibilities of influencing how the firm was run. In Firm A, entrepreneurial freedom was either given too early (to their first subsidiary managers, who reportedly misused it) or not at all (to their last subsidiary manager, who felt frustrated). This would suggest that headquarters staff ought to be able to give entrepreneurial freedom at a particular phase - not too early, but soon enough. In the case of headquarters-agents cooperation, the problems were more related to not knowing and trusting each other sufficiently.

If the overall picture is one of the strengthening of network closure being related to family SMEs agents' and subsidiaries' feelings of closeness and commitment, a weakening of network closure was related to negative feelings on the part of family 
SMEs' agents and subsidiaries concerning trust (the lack of it), mutual respect, open communication, and freedom to act according to one's own personality and creativity.

As regards the research question 3 of how network closure and structural holes explain the development of international operations in the French market, the predominant feature in our material - in line with the observations of Gargiulo and Benassi (2000) - was one of a lack of simultaneous maximization of the two network mechanisms; the firms tended rather to concentrate on network closure. Firm C came closest in our material to providing a counter-example: the firm here seemed to be seeking to embark on a strengthening phase in both network mechanisms, at least in turn, but partly also simultaneously - and indeed, the firm would merit longer-term follow-up with a focus on this aspect. Nevertheless, the evidence at present seems rather to suggest that a general concentration on increasing network closure runs counter to the longterm survival of family SMEs in the target market; once a problem with the partner appears, there are no networks to replace that partnership. As Gulati and Gargiulo (1999) suggested, the establishment of strong ties is important in the formation of interorganizational ties, but in a later phase, the flexibility offered by structural holes may be more important than network closure. Moreover, as argued by Podolny and Baron (1997), by focusing on network closure family entrepreneurs lose timely information on new opportunities.

Overall, it seems that in family SMEs there is a tendency to construct a single trustworthy social capital tie, instead of efforts to create additional social capital ties. We cannot at this point state that such a process is inevitable, but we did observe that due to 
concentration on just a few social capital ties, firms were obliged to go (for instance) to exhibitions to look for new cooperators. Although they had indirect bridges to French cooperators through their trustworthy French partners, these could be lost with the loss of the foreign partner. Family entrepreneurs may, naturally, form some strong connections through their partner's connections (Burt, 2010); however, there is a strong possibility that if problems arise, these secondary connections will follow the strong tie they know, leaving the family entrepreneurs without any international network ties in the specific market in question.

Altogether, in our material it appeared that the entrepreneurs gained support and resources from their cohesive networks, but that the obligations hindered their ability to pursue new opportunities. As regards social capital, the greatest threat to the family SMEs seemed to be related to the dependency on one foreign cooperator and, hence, to a lack of the social capital obtainable by spanning structural holes.

\section{Conclusions}

This study contributes to research on social capital and internationalization of SMEs in a number of ways: (1) It investigates the development of social capital in the international operations of family SMEs - hence responding to calls for more research on network development in the entrepreneurial process (Jack, 2010), especially in the context of internationalization (Prashantham and Dhanaraj, 2010). (2) We contribute to research on social capital by applying the notions of network closure and structural holes to the firm 
internationalization context, and by extending a theory on them in the context of family SMEs' international operations. (3) The study contributes to family business research by revealing how these mechanisms restrict and facilitate family SMEs' international operations, bearing in mind that despite the suitability of family SMEs for research on social capital (Salvato and Melin, 2008), it has been unclear how social capital affects their internationalization and foreign operations (Kontinen and Ojala, 2010).

In terms of managerial implications, this research has a number of recommendations to offer. Family entrepreneurs seem to have a tendency to concentrate on a limited number of foreign partners, and to neglect the building of new relationships that could help them in future challenges. They should acknowledge the need to develop new partners in international exhibitions, through customers, and so on. Family entrepreneurs should also take care not to select their cooperators very arbitrarily - and not trust unknown people too soon. However, once the cooperation has begun and trust has arisen, firm managers ought to give freedom to their subsidiary managers, gradually, allowing them do business with an entrepreneurial mindset. Excessive control is harmful for cooperation or for a good level of trust. Furthermore, firms should avoid showing distrust towards their subsidiary staff simply because of earlier, harmful events caused by previous managers.

Managers should look for help in networking: the person looking for suitable cooperators ought to know both the culture and the business field. Family businesses do not want to invest money on finding good relationships, but in the end they can lose money by not doing so, since they may end up having to deal with opportunistic or 
exploitative behavior. Family business managers could also be bolder in developing new network ties, even if they have found good existing ones. If cooperation ends for one reason or another, it is often too late to find a good partner to replace the one who was lost. Furthermore, family managers may have a tendency to hire new managers from among the existing staff. However, it may well be better for them to look for alternative network ties from outside the subsidiary.

\section{References}

Adler, P.S. and Kwon, S.-W. (2002), "Social capital: Prospects for a new concept", Academy of Management Review, Vol. 27 No. 1, pp. 17-40.

Arregle, J.-L., Hitt, M.A., Sirmon, D.G. and Very, P. (2007), “The development of organizational social capital: Attributes of family firms", Journal of Management Studies, Vol. 44 No. 1, pp. 73-95.

Brehm, J. and Rahn, W. (1997), "Individual-Level Evidence for the Causes and Consequences of Social Capital", American Journal of Political Science, Vol. 41 No. 3, pp. 999-1023.

Burt, R.S. (1992), Structural Holes, Harvard University Press, Cambridge, MA.

Burt, R.S. (2000), "The Network Structure of Social Capital", Research in Organizational Behaviour, Vol. 22, pp. 345-432.

Burt, R.S. (2005), Brokerage and Closure: An Introduction to Social Capital, Oxford University Press, US. 
Burt, R.S. (2010), Neighbor networks: Competitive advantage local and personal, Oxford University Press, US.

Chetty, S. and Agndal, H. (2007), "Social Capital and Its Influence on Changes in Internationalization Mode Among Small and Medium-Sized Enterprises", Journal of International Marketing, Vol. 15 No. 1, pp. 1-29.

Claver, E., Rienda, L. and Quer, D. (2008), “Family firms' risk perception: Empirical evidence on the internationalization process", Journal of Small Business and Enterprise Development, Vol. 15 No. 3, pp. 457-471.

Coleman, J.S. (1988), "Social Capital in the Creation of Human Capital”, American Journal of Sociology, Vol. 94, pp. S95-S120.

Coviello, N. (2006), "The network dynamics of international new venture", Journal of International Business Studies, Vol. 37 No. 5, pp. 713-731.

Gargiulo, M. and Benassi, M. (2000), “Trapped in your own net? Network Cohesion, Structural holes, and the adaption of social capital", Organizational Science, Vol. 11 No. 2, pp. 183-196.

Granovetter, M.S. (1973), "The Strength of Weak Ties", American Journal of Sociology, Vol. 76 No. 6, pp. 1360-1380.

Graves, C. and Thomas, J. (2004), "Internationalisation of the family business: a longitudinal perspective", International Journal of Globalisation and Small Business, Vol. 1 No. 1, pp. 7-27. 
Graves, C. and Thomas, J. (2006), “Internationalization of Australian family businesses: A managerial capabilities perspective", Family Business Review, Vol. 19 No. 3, pp. 207224.

Graves, C. and Thomas, J. (2008), “Determinants of the internationalization pathways of family firms: An examination of family influence", Family Business Review, Vol. 21 No. 2, pp. 151-167.

Gulati, R. and Gargiulo, M. (1999), “Where do interorganizational networks come from?", American Journal of Sociology, Vol. 104 No. 5, pp. 1439-1493.

Hoang, H. and Antoncic, B. (2003), "Network based research in entrepreneurship: a critical review", Journal of Business Venturing, Vol. 18 No. 2, pp. 165-187.

Huber, G.P. and Power, D.J. (1985), “Retrospective Reports of Strategic-level Managers: Guidelines for Increasing their Accuracy", Strategic Management Journal, Vol. 6 No. 2, pp. 171-180.

Jack, S.L. (2005), “The Role, Use and Activation of Strong and Weak Network Ties: A Qualitative Analysis", Journal of Management Studies, Vol. 26 No. 6, pp. 1234-1259.

Jack, S.L. (2010), "Approaches to studying networks: Implications and outcomes", Journal of Business Venturing, Vol. 25 No. 1, pp. 120-137.

Jack, S.L., Dodd, S.D. and Anderson, A. (2008), “Change and the development of entrepreneurial networks over time: a processual perspectice", Entrepreneurship $\mathcal{E}$ Regional Development, Vol. 20 No. 2, pp. 125-159.

Kontinen, T. and Ojala, A. (2010), "The internationalization of family businessess: A review of extant research", Journal of Family Business Strategy, Vol. 1 No. 2, pp. 97-107. 
Larson, A. and Starr, J.A. (1993), “A Network Model of Organization Formation”, Entrepreneurship Theory and Practice, Vol. 17 No. 2, pp. 5-15.

Nahapiet, J. and Ghoshal, S. (1998), "Social Capital, Intellectual Capital, and the Organizational Advantage", Academy of Management Review, Vol. 23 No. 2, pp. 242266.

Miles, M.B. and Huberman, A.M. (1994), Qualitative Data Analysis: An Expanded Sourcebook, Sage Publications, California.

Miller, D., Le Breton-Miller, I. and Scholnick, B. (2008), “Stewardship vs. Stagnation: An Empirical Comparison of Small Family and Non-Family Businesses", Journal of Management Studies, Vol. 45 No. 1, pp. 51-78.

Musteen, M., Francis, J. and Datta, D.K. (2010), “The influence of international networks on internationalization speed and performance: A Study of Czech SMEs", Journal of World Business, Vol. 43 No. 3, pp. 197-205.

OECD, (1997), Globalisation and small and medium enterprises (SMEs). Synthesis Report, Vol. 1, Organization for Economic Co-operation and Development, France.

OECD, (2003), Officially-supported export credits and small exporters, Organization for Economic Co-operation and Development, France.

Pettigrew, A.M. (1990), "Longitudinal field research on change: Theory and practice", Organization Science, Vol. 1 No. 3, pp. 267-292.

Podolny, J.M. and Baron, J.N. (1997), “Resources and relationships: Social networks and mobility in the workplace", American Sociological Review, Vol. 62 No. 5, pp. 673-693. 
Prashantham, S. and Dhanaraj, C. (2010), “The Dynamic Influence of Social Capital on the International Growth of New Ventures", Journal of Management Studies, Vol. 47 No. 6, pp. 967-994.

Rauch, J.E. (2001), "Business and Social Networks in International Trade", Journal of Economic Literature, Vol. 39 No. 4, pp. 1177-1203.

Salvato, C. and Melin, L. (2008), "Creating Value Across Generations in FamilyControlled Businesses: The Role of Family Social Capital", Family Business Review, Vol. 21 No. 3, pp. 259-276.

Svendsen, G.H. (2006), "Studying social capital in situ: A qualitative approach", Theory and Society, Vol. 35 No. 1, pp. 39-70.

Walker, G. Kogut, B. and Shan, W. (1997), "Social Capital, Structural Holes and the Formation of an Industry Network", Organization Science, Vol. 8 No. 2, pp. 109-125.

Yin, R.K. (1994), Case study research: Design and methods, 2nd ed., SAGE Publications, Newbury Park, CA.

Zahra, S.A. (2003), “International expansion of U.S. manufacturing family businesses: The effect of ownership and involvement", Journal of Business Venturing, Vol. 18 No. 4, pp. 495-512. 